\title{
Technológia-kontinuitási kérdések a somogyi vasvidék „izzó" vasbucái fényében
}

\author{
'GÖMÖRI JÁNOS \\ MTA VEAB Iparrégészeti Munkabizottság (Sopron), e-mail: forum.muzeum@gmail.com
}

\begin{abstract}
GömÖRl, J.: Questions of technological continuity in the light of the glowing iron blooms found on sites in county Somogy
\end{abstract}
Abstract: The study offers a comparison of the eight-century Avar, ninth-century Pannonian Carolingian and the tentheleventh-century post-Conquest period bloomery furnaces and the iron blooms found in their proximity, which suggested that a local population with stable craft skills preserving the late Avar traditions can be assumed in the light of the technological continuity.

Keywords: blommery furnaces, iron blooms, Early Medieval Times, continuity

\section{Bevezetés}

Nem tudni, hogy a 6. századi türkökhöz hasonlóan dicsekedtek-e egykoron a pannóniai (közelebbről a Somogy megyei) avarok, „hogy van nekik vastermő földjük”. A 10. század közepéről, a Bíborbanszületett Konstantinosz császár által készíttetett kivonatokból ismerjük azokat a jelentéseket, amelyeket Menandrosz 6. századi bizánci történetíró az 569. és az 576. évi, türkökhöz küldött bizánci követjárásokról feljegyzett. Igaz, hogy a leírás a türkök fennhatósága alatt élő iráni népre, a szogdokra (a mai Üzbegisztán területe) vonatkozik, mégis hiteles történeti forrásnak fogadhatjuk el arra vonatkozóan, hogy a Türk Birodalomban szervezett vaskohászat és kovácsmesterség létezett. Az idézet: „,...a türkök közül egyesek, akiket nyilván e célból küldtek ki, vasat kínáltak nekik megvételre, úgy gondolom azért, hogy bizonyságot tegyenek arról, hogy vannak vasbányáik. Azt beszélik ugyanis, hogy náluk a vas nem egykönnyen megszerezhető portéka. Ebböl arra lehet következtetni, hogy ezzel a fitogtatással arra céloznak, hogy van nekik vastermö földjük."1 Említethetjük Zamárdi vonatkozásában, hogy a nyugati türk területekről feltehetően ide is érkeztek mesteremberek, kereskedők. A Türk Birodalomból származó szogd ötvösök az avar kori Pannóniában is tevékenykedtek, akik szogd írással türk (ó-török) neveket véstek Somogy megyei fémtárgyakra. ${ }^{2}$

A kora középkori Kárpát-medence vasvidékei közül jelentős vastermelést tételezhetünk fel Pannónia mai dunántúli részén, ahol jelenleg két nagyobb körzet vasércbázisairól és kohászati lelőhelyeiről állnak rendelkezésünkre részletesebb régészeti adatok. Ez a helyzet azonban elsősorban a kutatási intenzitás mai állapotának eredménye. $A$ Kohászati Történeti Bizottság, amelyet az 1950-1960-as években Kiszely Gyula, ${ }^{3}$ a diósgyőri vasgyár irodavezetője szervezett, 1968-ban adta ki az első alapvető, interdiszciplináris jellegű kohászattörténeti munkát. Nováki Gyula, soproni régész az északkelet-magyarországi vasvidék mellett még csak a Balatontól északra eső területről (Sopron és Vas megyékből) adhatott részletesebb leírásokat a hiteles ásatásokból ismert vaskohókról. ${ }^{4}$ Nováki kohófeltárásait 1971-től a soproni „Liszt Ferenc” Múzeumból folytattuk, ${ }^{5}$ több esetben geofizikai leletfelkutatásokkal. ${ }^{6}$ 1980-tól az MTA Veszprémi Területi Bizottságának - Sopronban megszervezett - Iparrégészeti Munkabizottsága szervezésében, műszaki- és természettudományos szakemberek bevonásával folytatódtak a tervszerű vasrégészeti kutatások? Kezdettől fogva a Munkabizottság tagja, titkára, illetve alelnöke volt Költő László kaposvári régészeti osztályvezető. Folyamatosan segítette a Munkabizottság Somogy megyei kohóásatásait, és maga is számos vasipari lelőhely leletmentését végezte el, ${ }^{8}$ emellett terepbejárási kampányokat szervezett újabb kohólelőhelyek felfedezésére. ${ }^{9}$

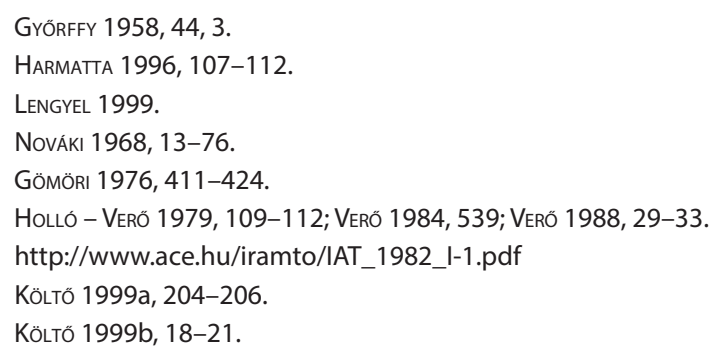


A Győr-Moson-Sopron, illetve Vas megyék területén korábban megismert avar kori ${ }^{10}$ és Árpád-kori ${ }^{11}$ vastermelő helyek mellett Somogy megye kohászatrégészeti emlékeinek interdiszciplináris értékelése tovább gazdagíthatja ismereteinket a 8. századi avar, a 9. századi Karoling-kori és a 10. századi magyar honfoglalás, majd államalapítás korszakainak egymást váltó hatalmi struktúráiról is. Fontos kérdésekre kaphatunk választ a gazdaság-, ezen belül a vasipar szervezéséről, a kohótelepek termelékenységéről, technikai színvonaláról. Az egyik fontos kérdés, hogy az alkalmazott technológiai eljárások folyamatossága, vagy megszűnése milyen összefüggésben lehetett az egyes területek feletti - esetleg néptömegeket is elmozdító - hatalmi változásokkal? A kérdés vizsgálata alapvető fontosságú a népességi kontinuitás ${ }^{12}$ kutatása szempontjából is. A vasipari objektumok abszolút kora több módszerrel meghatározható, ${ }^{13}$ egymástól független kontrollvizsgálatok sorozataival pontosítható. Így egy-egy kohó elvileg besorolható a késő avar kortól, a Karoling-koron, illetve a magyar honfoglalás koron át az Árpád-korig tartó relatív kronológiai sorrendbe. Ha pl. a korábban használt kohótípusokat új formájú és méretű bucakemencékkel váltják fel, megvizsgálandó, hogy ez a váltás más hagyományú néptömegek beáramlásával, az anyagi kultúra drasztikus megváltozásával járt-e együtt, vagy a társadalom és gazdaság más elemeinek jelentősebb változása nélkül csak a vasipar területén történt olyan innováció, amelynek célja egyedül az előállított vas mennyiségének növelése, vagy a kovácsolható vas minőségének javítása volt.

A népességbeáramlásokkal járó területfoglalások, hatalomváltások után a különböző helyi mesterségek hagyományai tovább élhettek, ha a hódítás nem járt drasztikus népességcserével. Emellett az új elit igényeit és a "divatot" követő kereslet megváltozása a - korszakonként is három-négy szinten termelő - „kézművesipar" tevékenységét különböző mértékben érinthette. Először tehát a feltárt kohótelep - ipari jellege szerinti - szintbesorolását kellene elvégeznünk a kohók és a telep objektumrendszere alapján. Majd lehetőleg több módszerrel keltezni kell a kohót, mert vele együtt az egész vasolvasztó telepet besorolhatjuk a kronológiai sorrendbe.

I: Az alsó, legszélesebb szinten a falusi, önellátó háziipar (a szövéstől a kerámiakészítésig és famegmunkálásig) a leginkább hagyományőrző.

II: A következő szintet az önellátó mezőgazdasági munka mellett, speciális ipari szolgáltatást végzők csoportjai jelentik. Az ipari produktumokkal adózók között a korai középkorban már voltak vaskohászok és kovácsok is. Múhelyeik, kohóik az avar korban a faluban, gyakran hatalmi központok közvetlen közelében találhatók. Az Árpád-korban ${ }^{14}$ a településen kívül létesítettek kohótelepeket, ${ }^{15}$ de a kovácsmühely a faluban volt.

III: Magasabb szinten álltak a piacra termelő, részben speciális termékfajtákat eloállító szabad iparosok, esetleg faluközösségek, vagy etnikai csoportok.

IV: A vasipart tekintve, olyan manufaktúraszerú ipartelepek is létesültek, ahol egy-helyen történtek a különböző munkafázisokhoz tartozó műveletek, a vasérc-előkészítéstől, a faszénégetéstől és a vas kohósításától a kovácsolásig, illetve az igényesebb felszerelések előállításáig. Ez jellemző a Karoling-kori pannóniai Ostmark grófságainak néhány kohótelepére. ${ }^{16}$

V: Elöfordulnak több száz, sőt ezernyi bányagödörből álló vasércmezők, amelyek gyakran a próbaolvasztásokhoz épített vasolvasztó kemencék is megtalálhatók. Ezek a központilag szervezett vastermelés bizonyítékai. ${ }^{17}$

VI: A koraközépkori ipar legmagasabb szintje a királyi, vagy "grófi" központokban ${ }^{18}$ létesített változatos kézmúves-mủhelyek sora, a luxusigényt kielégítő iparosok, köztük kovácsok mühelyei.

\section{A kohótipológia fontosabb eredményei és kérdései}

A kohótipológia nem zárja ki, inkább támogatja a 8-9. századi kohászati hagyományok továbbélését a 1011. században. A gödörmủhelyek oldalfalába beépített kohók mérete és formái, valamint a használt mellfalazatok és fúvókák alapján úgy látszik, hogy a Dunántúl e szempontból kutatott területein ugyanazt a vaskohászati technológiát használták a 10. századtól (Bodrog-Alsóbü, ${ }^{19}$ Somogyfajsz-lvató tó20), amely már a késő avar korban is kimutatható (Bátaszék-Nagyorros ${ }^{21}$ ). Viszont az avar korból ismert félig földbemélyített, salakcsapolós kohók és a földfelszínre épített, szabadon álló kohók már nem jellemzőek a 10-11. századi kohászati telepeken.

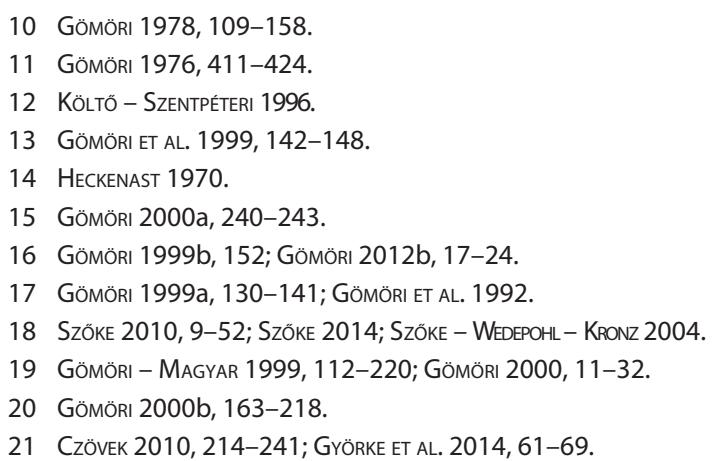


Bár - a vegyes érvelés veszélyeit szem előtt tartva - meg kell jegyezni, hogy az avar korra keltezett kohótelepek mellett (Tarján-puszta, Nemeskér-Rétrejáró alja, Magyaratád-Kéri határra dűlő) a 10. századi törzsi helynevek is továbbéltek napjainkig, ennek alapján esetleg feltételezhetnénk, hogy 900 után is folyhatott itt vaskohászati tevékenység. Jelen ismereteink szerint a különböző kohászati objektumok rendszere, tehát a munkaszervezés is eltérő volt'22 az avar korban és a 10-11. században, ennek alapján nem bizonyítható, hogy a törzsi helynévvel jelölt helyeken törés következett volna be a vasipari termelésben 900 után, amennyiben feltételezzük, hogy a fegyveres, törzsi birtokbavétel a termelés további biztosítása és felügyelete miatt történt. Az eddig csak az ipartelep jellegének és keltezésének céljából szondázott nemeskéri kohászati centrum faszénből mért kalibrált ${ }^{14} \mathrm{C}$ adatai ${ }^{23}$ támogatnák kronológiailag ennek a zökkenőmentes vastermelés-folyamatnak a feltételezését, viszont régészeti bizonyítékunk erre Nemeskérről még nincs.
$68,3 \%$ (1 szigma) confidencia szinten:
$718 \mathrm{cal} . \mathrm{AD}$
740 cal. AD
766 cal. AD
$892 \mathrm{cal}$. AD
95,4\% (2 szigma) confidencia szinten:
$682 \mathrm{cal} . \mathrm{AD}$
$958 \mathrm{cal} . \mathrm{AD}$

A közeli Sopron-Potzmann-dúlő kohó és műhelytípusai, valamint a jellegzetes ércpörkölő gödrök alapján viszont feltételezhető a helyi avar kohótípus és a 10 . századi mühelygödör egymás melletti használata. ${ }^{24}$

A földfelszínre épített kohók (Nemeskéri típus) megjelentek ${ }^{25}$ már a késő avar korban (Tarján-puszta-Vasas-föld, Ravazd-Simahegy), és általánosan használatban voltak a Karoling-korban, a Savaria és a Fertő-Hanság közötti területen (Dénesfa-Szikas-dülőben. ${ }^{26}$ Iván-Dudás-dűlöben, ${ }_{1}^{27}$ Csepreg-Tömördi erdőben). Kérdés, hogy ezekben - az úrtartalmukban a beépített kohókhoz hasonló, de esetenként kissé szélesebb medence-átmérőjü - magas felépítésú aknakemencékben valóban a 10-12. századból megismert technológiával készithették-e a vasbucákat? Vasolvasztási kísérletsorozatok eddig - egy 1993. évi soproni próbaolvasztás ${ }^{28}$ kivételével - csak az Árpád-korban általánosan elterjedt mühelygödör oldalába beépített (Imolai-29 majd a Somogyfajszi típusú30 ${ }^{20}$ kohókban történtek.

\section{Vasbuca-leletek}

Az avar kori- és a Karoling-kori vasbucák, illetve a 10-11. századi vasbucák méreteinek összehasonlításai elárulhatnak valamit e korszakok kohászati technológiáinak hasonlóságáról és különbözőségeiről. Az összehasonlítás a kémiai összetételek és a metallográfiai képek elemzésével is elmélyíthető, mert ezek az alapvető archeometriai vizsgálatok az alább említendő bucákon megtörténtek.

Ha a feltárt mühelyek termelékenységét, a gazdaságos vaskihozatalt szeretnénk meghatározni, eredményre vezethet, ha figyelembe vesszük az egy-egy vasolvasztásnál előállított vasbuca súlyát, a műhely kohóinak számát, az elhasznált fúvókák számát (vagy becsült mennyiségét) és a salakhalmokban talált vassalak becsült összsúlyát. Mindezekhez a lelőhely vasércei $\mathrm{Fe}_{2} \mathrm{O}_{3}$ és számított vastartalmának, valamint a salakok vastartalmának - archeometriai elemzésekkel meghatározható - átlagértékét is fontos megismernünk. ${ }^{31} \mathrm{~A}$ kohóbélések vizsgálatából hozzávetőlegesen megbecsülhetjük, hogy hányszor olvaszthattak egy-egy kohóban.

Somogy megye területérôl eddig három lelőhelyről, összesen hat vasbuca került elő. Ezek közül 4 bucát 10. század végi vasolvasztó mühelyben (Somogyfajszon) tártak fel. Egy bucát (késő avar korinak feltételezhető) kohótelep közelében találtak (Lábod). Ezek a vasbucák egykor - fehéren izzó állapotban - Somogy megyében „születtek." Jelképesen szólva, „apjuk" helyi gyepvasérc, „anyjuk" helyben létesített vaskohó, „akinek” medencéje fölött, nehéz fújtatás után, $1200{ }^{\circ} \mathrm{C}$ körüli hőmérsékleten kialakult a kohászok (vasasok) által várva-várt vastömböcske, a még szivacsos, salakos vasbuca. A kohó mellfalazatának leemelése után bukkant elő ez a

22 GÖMÖRI 2001a, 17-35; GÖMÖRI 2001b, 33-38

23 ATOMKI Deb-978 Nemeskér, Hertelendi Ede mérése, GöMÖRI 2000a, 251.

24 GÖMÖRI 2000a, 131. és 132. képek.

25 GöMÖRI 1980, 317-345.

26 GÖMÖRI 1984, 337-339.

27 GömÖRI 1988, 108. fig. 13-14.: az iváni mellfalazat és a kohó medencéje.

28 https://drive.google.com/file/d/15jWNJNcyPIk6UhKjZYSgt789YzPkdWA_/view A kísérleti vasolvasztást a Soproni Múzeum kertjében, kópházi vasérccel Gömöri János vezetésével, a nemzetközi Scarbantia diáktábor közreműködésével végeztük. A vasérc-lelőhelyről: GöMÖRI ET AL. 1992. (A bányamező, 'Pingenfeld' régészeti kutatása a 85-ös főút építését megelőző régészeti feltárásokkal 2017-ben Ujvári Ferenc, 2018-ban Györke Réka vezetésével folytatódott.)

29 Zoltay 1968, 172-232.

30 THIELE 2014. Az első demonstrációs vasolvasztást a somogyfajszi Őskohó Múzeum melletti kísérleti műhelyben (ÁGH - GömöRI 1999a, 196, fig 3.), a Korotnai-patak mellett gyűjtött gyepvasércből, „Fajszi típusú” kohókban Gömöri János és Költő László 1997. május 30. - június 1. között végezte, a „Hagyományok és újítások a korai középkori vaskohászatban” c. nemzetközi szimpózium alkalmával, a Dunaferr Somogyország Archeometallurgiai Alapítvány támogatásával.

31 VASTAGH 1977, 103-105; GÖMÖRI - TöRÖK 2002, 375-381. 
fehéren izzó tömb, amelyet a marcona, de csillogó szemű vasasok egy fakalapáccsal vertek, tömörítettek, amíg immáron rózsaszínüre, pirosra, majd kékesszürkés árnyalatúra változott, miközben a forró vastömbből, kifröcsögtették, kiszorították a salakot. Ezután mondhatták elégedetten, hogy megszületett a kovácsolható vas. Hogy ebben biztosak legyenek, újrahevítés után - egyes esetekben - éles baltát helyeztek az újra vörösre izzított bucára és a balta fokára erőteljes ütéseket mérve, behasították a vastömböt, hogy láthassák belső tisztaságát. Ez történt valamikor a késői avar korban Lábod-Petesmalom lelőhelyen is, ahol azután, jó 1200 évvel később Költő László régész, egy kohászati mühely kemencemaradványainak közelében megtalálta a 22,5×25,5 centiméter méretü, 9,5 kilogrammnyi vasbucát (1. ábra 4.).32

A másik kohászati mühelyben négy kerek, 10×7-17×5 centiméter méretű $(1,72-3,7$ kilogramm) vasbuca (1. ábra 1-3.), közvetlenül a kohó mellett, e sorok írójának ásatásán került elő, a Somogyfajsz-Ívató tó lelőhelyen. A régészeti és fizikai kormeghatározásokkal a 10. század végére keltezhető somogyfajszi vastermelő üzemet - feltételezésünk szerint - Koppány vezér vereségének hírére menekülésszerúen hagyhatták el a kohászok, még az értékes vasbucákat is hátrahagyták.

A harmadik Somogy megyei lelőhely, ahol korábban vasbucát találtak, a Nagyberki melletti Szalacska (földvára?). ${ }^{33} \mathrm{Az}$ itteni félbevágott buca (1. ábra 5.) keltezése bizonytalanabb, de feltehetően egy késő római kori hadianyag-szállítmánnyal kerülhetett Pannonia Prima területére. A 29×22×12,6 centiméter méretű, 26 kilogramm súlyú buca eredetileg hasonló lehetett, mint az 50-60 kilogramm közötti két soproni, egy hévízi és a hat példány keszthely-fenékpusztai vastömb (5 ékelt buca és egy hasonló súlyú üllö). ${ }^{34}$ "A szalacskai buca a

32 KöLTŐ - FEHÉR 2016: a szegedi archeometallurgiai konferencián elhangzott előadás; A 2017. évi prágai archeometallurgiai konferencián a Lábod-Petesmalom avar-kori és a Zalavár-Vársziget 9. századi hasított vasbucáinak összehasonlító vizsgálatát mutatta be a magyar kutatócsoport:TöRöK ET AL. 2018. A Bányászati Kohászati Lapok, Kohászat hasábjain is megjelent dolgozatból kiderül, hogy a kinézetre és súlyra igen hasonló lábodi és zalavári bucákat nem egy helyen készítették. A lábodi nagyon heterogén szerkezetű, nagy foszfor tartalommal, amitől izzó állapotban kovácsoláskor törékeny lehetett, esetleg már a korabeli kohászok selejtesnek minősíthették a helyben készült darabot. Ezzel ellentétben a zalavári bucát feltehetően újraizzították, tömörítették. A zalavári buca archeometallurgiai értékeléséhez kívánkozik egy megjegyzés: Feltételezem, hogy viszonylag magas mangántartalma talán segíthet a származási helyének meghatározásában. Véleményem szerint a Szőke Béla Miklós (SzökE 2010; SzőkE 2014.) által felvázolt történeti háttér alapján valószínű, hogy - Priwina kérésére - Liupram salzburgi érsek által a zalavári központ (Mosapurch, Urbs Paludarum) egyik templomának felépítésére a 850-es években küldött mesteremberek, köztük kovácsok hozták magukkal mesterségbeli tudásuk és szerszámaik mellett a legfontosabb félkész „alapanyagokat" (üveg nyersanyagokat, vasbucákat és a harangöntéshez való bronzot). A zalavári buca metallográfiai vizsgálatainak értékeléséből Török Béla (Тö̊öк 2017; Török 2018.) azt a következtetést vonta le, hogy: „....az avar, Karoling- és honfoglalás kori „,buca-technologia” jellemző kohóinak feltételezhető méreteit, kapacitását és 10-30\%-os vas kihozatalát tekintve [10] [11] ilyen nagyméretú bucák aligha születhettek egy adag kohósítása alatt, az általunk eddig ismert kora középkori pannóniai buca kemencékben." Ezért feltételezi, hogy: „....az sem kizárható, hogy a nagyméretű zalavári bucát több kisebb, akár a korai középkorban „szokványos” 1-3 kg-os vasbuca többszörös újraizzítás közbeni összetömörítéséből készítették." Itt figyelembe kell vennünk, hogy a zalavári bucák feltételezhető készítési helye valahol nyugatabbra, a Karoling Birodalom „törzsterületén” lehetett, ahol viszont nagyobb méretű bucákat is előállítottak. A Nemeskéri típushoz hasonló szabadon álló, korai középkori agyagfalú kohókat széles körben használtak a bajor területen a Karoling-korban (HENSCH 2006, 402, Abb. 41, Abb. 44.). A dél-skandináviai lelőhelyeken (JoutTJäRVI - MARTENs 1977, Abb. 4-5.; ESPELund 2013, fig. 5.) a viking periódusban szabadon álló agyagkemencék használata általánosan elterjedt. A pannóniaiakhoz hasonló medence-átmérőjű kohóikban előálított vasbucák, sokszor 10 kilogrammnál súlyosabbak voltak. A hasított vasbucáikat már részletesen ismertették (MARTENS 1977, Abb 6: Mösstrand, bucaátmérő: 26 cm, súly: 12,5kg; Espelund 2013, 32-33, fig. 9.). A bucák bevágásának elsődleges célja valóban a vasminőség vizsgálata lehetett, de legalább olyan fontos volt, hogy a településektől távoli kohótelepekről - a nehezen járható ösvényeken - elszállítandó vasanyagot célszerűen a teherhordó állatok hátára tudják málházni, a speciális nyergen átvetett kötelek segítségével. A közbülső térség dán kutatása (Voss 1989, 153.) - az általánosan elterjedt salakgödrös kohók mellett - a mühelygödör oldalába félig bemélyített, Kr. e 1. század - Kr. u. 1. század közötti kohókat is említ („Skovmark-type furnace”), amelyek mellnyílását a pannóniai avar kohókhoz hasonlóan agyag mellfalazattal zárták le, az ottani agyaglapokon csak lyukon, és nem beépített fúvókán keresztül fújtattak (JoutTuÄRVI - Voss 2011, fig. 18-19.). Ezek a kohóformák kelta műhelyhagyományokat követnek és használatban voltak a korai római császárkorban a barbarikumi területeken. Figyelembe véve az Európa szerte feltárt több ezer kohómaradvány rengeteg formai variánsát, és a rekonstrukciók bizonytalanságait valódi „technológia-transfer” mühelyhagyományok átadása csak olyan térségek között tételezhetünk fel, ahol régészetileg és történetileg is kimutatható valamilyen szorosabb kapcsolat. (pl. a 8-10. századi Kárpát-medence vonatkozásában nyugati hatásként a bajor területek, keleti hatásként fóleg Etelköz, ukrajnai és moldáviai lelőhelyek jöhetnek számításba.

33 Központi Kohászati Múzeum: Leltárkönyv adatai: 61.7 .1 leltári számú vas-buca. Anyag, technika: átkovácsolt buca. Átm.: $32 \mathrm{~cm}$. Lelöhely: Szalacska. Kora: nincs bejegyzés. A tárgy állapota: alaktalan. Megszerzés módja: ajándék. Ajándékozó: nincs bejegyzés. Megszerzés időpontja: 1956. Tárgy elhelyezése: kiállításban (Felsőhámor, állandó kiállítás, 1. emelet, vasgyártás terme). Leltározó neve: Nováki Gy.; HeGEDÜs 1961; RozsNokı 1979.

34 SÁGı 1979; Gömörı 1981, 11, 4. ábra; Rozsnokı 1979; Gömöri János és Heinrich-Tamáska Orsolya prágai előadása: „Archaeological and historical data for the heavy, unique split iron blooms found in Pannonian late Roman fortresses" (IRON IN ARCHAEOLOGY Bloomery Smelters and Blacksmiths in Europe and Beyond. Prague, May 30 - June 1 2017. Conference organized in honour of Radomír Pleiner in the 50th year of the CPSA; PLEINER 2000, 242: a nagy pannóniai bucák metallográfiai elemzéséröl. 


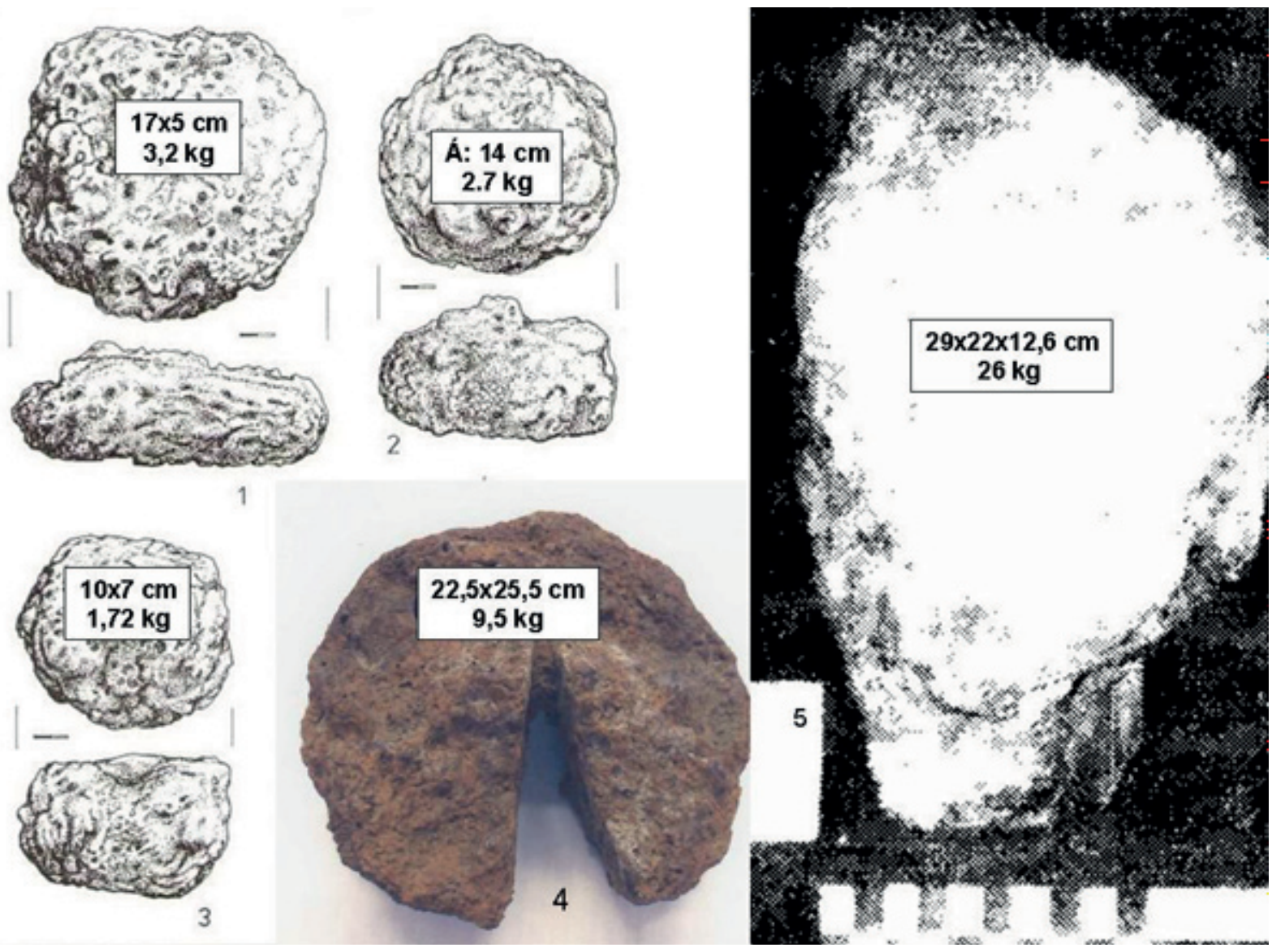

1. ábra. Somogy megyei vasbucaleletek. 1-3. Somogyfajsz-ĺvató tó, 10. század végi vasolvasztó mühely (GömöRI 2000, 155.), Öskohó Múzeum, Somogyfajsz; 4. Lábod-Petesmalom, 8-9. század (Költó - FEHÉR 2016.) Rippl-Rónai Múzeum, Kaposvár; 5: Szalacska, (HEGEDÜS 1961, XVI. tábla, 2, mint középkori félbuca; SÁGI1979; RozSNOKI1979, 1d. ábra, mint késő róma, 4-5. századi félbuca. Központi Kohászati Múzeum, Miskolc-Diósgyőr

belöle vett minta alapján kevesebb karbont tartalmaz, mint akár az Sopron/l, akár a Hévíz/l. Szövete kívülről befelé haladva változik, ferritesből a ferrithálós perlitig fokozatos az átmenet."35 Tehát kovácsolható vas, ellentétben az említett lelőhelyek részben öntöttvas-szerű részeket tartalmazó, helyi túlhevítésen átesett nagy, késő római kori vasbucáival. A római korból egyelőre kohót nem, csak kovácsműhelyeket ismerünk a Dunántúlról, helyi antik hagyomány ezért az avar kori vaskohászat esetében egyelőre nem mutatható ki. ${ }^{36}$ Megjegyzendő, hogy a petőházi római villa 4. századi, fából épített kovácsmúhelye ${ }^{37}$ közelében egy $20 \times 16 \times 9$ centiméteres, 10,5 kilogramm súlyú szögletesre kovácsolt vasbuca került elő. ${ }^{38}$ Ez a durván alakított buca láthatóan nem a Siscia vidékéről északra szállított, szabályos rúdvasformára kovácsolt kereskedelmi szállítmányok valamelyikével került ide. Míg azok (Kapospula-Alsóhetény-puszta, Dunaújváros/Intercisa, Regöly lelőhelyekről ${ }^{39}$ ) 5-6 kilogramm körüli súlyukkal a nagykereskedelmi szabvány szerint kerültek piacra, a petőházi buca „kilóg a sorból”, és ezzel talán első jelzője lehet olyan, még fel nem fedezett késő római kori (villagazdasági) buca-tűzhelyeknek, amelyekben akár 10 kilogrammnyi vasbucákat is elő tudtak állítani.

Egy avar kori lakótelepen talált fél vasbuca ismert Hajnal Zsuzsanna kölkedi ásatásából: „átmérője: 8,5 cm, vastagsága: 2,5 cm, súlya: 176,15 g $\mathrm{g}^{\prime \prime 4}(1,7615 \mathrm{~kg}$, tehát az egész vasbuca méretben nagyjából a 3,7 kilogrammos somgyfajszi bucához hasonlíthatott).

35 Rozsnokı 1979, 27. ábra

36 GöмÖRI 2012a, 32.

37 GömöRI 2000a, 84. kép, VII. tábla 1-4.

38 A bucát Gabrieli Gabriella a villa kőépületének 1985. évi feltárásakor, kovácsszerszámokkal együtt találta. Itt is köszönöm, hogy a vasakat az általam feltárt kovácsmühellyel együtt adhattam közre. GöMößI 2000a, 85. kép.

39 Tóth Endre (1987-88), Bóna István (1969) és Szabó Géza (2012) leletei, e leletcsoport bemutatására itt nem térünk ki.

40 Hajnal Zsuzsanna (Magyar Nemzeti Múzeum) szíves levélbeli közlése, amit ezúton is megköszönök. Illetve előadása a 2015. évi debreceni Kontinuitás-konferencián. 
Egy távolabbi (Eperjes-Csikós tábla), avar korra keltezett 30×20×10 centiméter méretű, 8 kilogramm súlyú vasbuca, bár nem ékelt, de méreteiben a zalavári és a lábodi bucákra hasonlít. A Bálint Csanád által közölt vasnyersanyag mérete alapján ${ }^{41}$ is arra gondolhatunk, hogy az avar korban, illetve a Dunántúlon a Karolingkorban kétféle kohászati technológiai eljárás is gyakorlatban lehetett. Egyik a kohók formai hasonlóságából is sejthető, Árpád-korig továbbélő technológia, a félig, vagy egészen a munkagödör oldalába épített kohókkal (Tarjánpuszta - Bátaszék - Bodrog-Alsóbủ - Somogyfajsz stb. csoport a kisebb vasbucákkal).

A másik technológiai csoport, a szabadon álló, magas felépítésű, de az előzőekhez hasonló úrtartalmú, kissé szélesebb medencéjú kohókkal, amelyekhez a nagyobb vasbucák, Lábod, esetleg Zalavár és az alföldi Eperjes tartozhatnának. Két utóbbi lelőhellyel kapcsolatban azonban megjegyezendő, hogy azok bucái import darabok lehetnek. A Magyar Nemzeti Múzeum kiállításán látható zalavári bucákat ${ }^{42}$ esetleg a salzburgi érsek küldhette 850 körül a kovácsokkal és más ipari nyersanyagokkal, például a Rajna-vidéki üveg nyersanyagokkal. ${ }^{43} \mathrm{~A}$ nemeskéri ${ }^{44}$ és részben a zamárdi kohótelepekhez hasonló vaskohászati centrumok a Karoling Birodalomhoz csatolt bajor területek hatalmi központjai mellett is múködtek ${ }^{45}$ sokszor részleteikben is hasonló objektumokkal.

\section{Összefoglalás}

Az általunk vizsgált Észak-Nyugat- és a Dél-Dunántúl területét a korai középkorban három irányból érték kolonizációs hatások. Kelet felől a közép avar kortól (a 670-es évektől) feltételezhető ${ }^{46}$ népesség beáramlás, amely egy-két évszázados folyamat kezdete lehetett, ez az Avar Birodalom népcsoportjainak anyagi kultúráját sok vonatkozásban egységesítő, de a politikailag megosztó „onogur” kolonizációnak feltételezhető. Nyugatról a korábbi germán betelepedéseknek (Zamárdi és Kölked vasipari szempontból is érintett), majd a Karolingkori bajor (német) kolonizációnak maradtak régészeti nyomai és írott forrásai. Északról, illetve délről az Avar Birodalom korábbi határterületeiről a szláv kolonizáció hatása érvényesült. Ez utóbbi a vasipar szempontjából a déli szláv szavak (kovács, kalapács) átvételében is megnyilvánul. De ősidőktől tartja magát az uráli eredetű 'vas' szavunk és a fő kovácsszerszámok nevei (verő, fogó, üllő). Kohászati vonatkozásban a korai Árpád-kori „Vasvári típusú" kohászati mühelyek Vas megyei lelőhelyei esetleg alpesi szláv előzményekre mehetnek vissza. A nyugati szláv morva kohók a 8. században jelentek meg, két típusuk hasonlít a 7-8. századi pannóniai avar kohókhoz, a harmadik Želechovicei típus az avaroknál és a magyaroknál eddig nem ismert.

A német- és a szláv kolonizációs hullámok azért nem tudták teljesen saját képükre formálni a Kárpát-medence sík- és dombvidékeinek népességét az Avar Birodalom szétesése után sem, mert annak Duna és Tisza vidéki részeit akkora már jó 200 éve, még avar uralom alatt elkezdték benépesíteni és „kolonizálni” a korai történeti forrásokban ungri (többes szám), néven nevezett onogurok, akiket a magyar honfoglalás korában a német évkönyvek alkalmanként az avarokkal azonosítottak.

Ha ebben az összefüggésben vizsgáljuk az avar kori, a 9. századi és a 10-11. századi dunántúli vaskohászati kontinuitás kérdését, vagy a korszakokhoz köthető technológiai változások jellegzetességeit, érthetőbb lehet az alapvető kézművesiparoknak az alapnépesség egyéb hagyományaival való továbbélése.

Ebben az áttekintésben inkább kérdések feltevésére törekedtem, mint valamiféle elmélet felvázolására. Beszéljenek maguk a kohászati lelőhelyek.

Vizsgálati szempontunkból ${ }^{47}$ az egyik fő kérdés, hogy az avar hatalom 800 körüli összeomlását követő változásokat kísérte-e egyes településeken a kézművesség újjászervezése a 9. század folyamán? Vagyis feltétélezhető-e a helyi, hagyományos (avar kori) kézműves technológiák kontinuitása és a termelés-szervezési modellek 9. századi továbbélése? Ebből a szempontból fölöttébb fontosak a mủhelyek, az égett ipari kemencék archeomágneses és termolumineszcens kormeghatározásai, illetve ugyanazon objektumok faszeneinek ${ }^{14} \mathrm{C}$ módszerekkel való datálása, a kerámia-tipológiai alapú keltezések pontosítására. A 9-10. századra való

41 Az eperjesi buca feltehetően partiumi, vagy erdélyi kohótelepről származik és esetleg a só-szállító utak valamelyikén került a tiszántúli kovácsokhoz. GömÖRı 2000a, XII. tábla B1-2.

42 SZÖKE 2014.

43 SZÖKE - WEDEPOHL- KRONZ 2004.

44 GÖMÖRI 1978; GÖMÖRI 1980.

45 HeNsCH 2016, 32. Észak-Bajorországban az Amberger Erzberg melletti Eglsee közelében olyan 8/9. századi faszénégető boksa alapot tártak fel, mint a Nemeskér-Tüskésrét lelöhely, szintén a 9. századra keltezett boksái (GömöRl 1980, 336-337, Abb. 18-19.).

46 Nem lehet tárgya e dolgozatnak a több kutató által vitatott (BÁLINT 2004.) középavar kori „onogur” népcsoport sorsának kérdése. Vasipar-régészeti vonatkozásban tény, hogy eddigi ismereteink szerint a 7-8. században valamikor Kuber és kíséretének beköltözése körüli időből ismerjük a legkorábbi avar kohókat Pannóniából. Ezeknek a kohóknak megtalálhatók az ukrajnai párhuzamai is, bolgár-alán, vagy szláv környezetben (GöMörI 2000a, 14; GöMöRI 2008, 63-81.) Nem térhetünk ki itt a „kettős honfoglalás” kérdésére sem, véleményem szerint (is) folyamatos migrácós hatás érte keletről a Kárpát-medencét a 7-9. századok folyamán.

47 Summaries of the Symposium „Archaeological remains of the Early Medieval crafts, with special regards to the iron production and smithing (8th -10th century) / A korai középkori kézművesség régészeti emlékei, Szeged, 2016. 
keltezés ugyanis ebben az esetben éppen a vasipar-technológiai kontinuitás kérdésére nem ad választ, bár a fazekasipari hagyományok továbbélése egyes körzetekben kimutatható. ${ }^{48}$

Az alapvető kézműves- és manufakturális iparok tekintetében a korai középkori Kárpát-medence dunántúli részén a 800 utáni Karoling-bajor kolonizáció, majd a 900 körüli magyar honfoglalást követő gazdasági, társadalmi átrendeződések időszakában eltérően alakultak a kézművesiparok folyamatosságának lehetőségei. A 800-as években, a Rábától nyugatra, az „inter Sabariam et Carnuntum” áttelepített avarok önállóságának felszámolása után - feltehetően a prefektusi határvédelmi egységek hadi felszereléseinek készítőiként - tovább dolgoztatták az avar kohászokat és kovácsokat, erdők mélyén, sokszor a bányamezők közelében kialakított nagy ipartelepeken (Nemeskéri típusú múhelyek). ${ }^{49}$ Ezek a jelentős (IV. típusú) ipartelepek - amelyek kohói zömmel szabadon álló, magas felépítésű, salakcsapolós, agyagból épített kemencék voltak - szerkezetükben nagyon különböztek a korábbi, avar kori (II. típusú), falvakhoz kapcsolódó kohászati műhelyektöl, amelyekben az önellátó, mezőgazdasággal és nagyállattenyésztéssel is foglalkozó szolgáltatók(?) állították elő a szükséges vasmennyiséget..$^{50}$

A pannóniai Ostmark 9. századi kohótelepeinek egyes objektumaihoz analógiaként figyelembe vehetjük az ingolstadti Karoling-kori vasipari telepet. ${ }^{51} \mathrm{~A}$ nemeskéri ${ }^{52}$ és részben a zamárdi kohótelepekhez hasonló vaskohászati centrumok a Karoling Birodalomhoz csatolt bajor területek hatalmi központjai mellett is múködtek, ${ }^{53}$ sokszor részleteikben is hasonló objektumokkal.

Ugyanebben az időszakban Zalavár (Mosaburg) grófságban ${ }^{54}$ új, szinte városias igényű - a római kor után Pannónia területén (szinte-) teljesen elsorvadt - iparágak jelentek meg újra, a Salzburgi Érsekség által küldött bajor(?) mesteremberek alkalmazásával, import nyersanyagok használatával. Tehát részben az évszázadokkal korábbi római kolonizációs modell - más történelmi körülmények közötti - alkalmazását tételezhetjük fel..$^{55} \mathrm{Ez}$ a bajor kolonizációs folyamat azonban 900 után hozzávetőlegesen egy évszázadra megszakadt. Az etnikailag tarka képet mutató késő avar kori és 9. századi pannóniai népesség ${ }^{56}$ egyik jelentős törzscsoportját alkothatták a késői avarok (nyugati forrásokban és szláv környezetben a 9. század vége felé már gyakran ungri néven is említve, együtt a magyarokkal). A harmadik kolonizáló törzscsoportot a szlávok különböző törzsei, népcsoportjai alkották. A vasipart tekintve, Priwina által a mosaburgi birtokaira behívott szlávok a korábbi avar hagyományoktól teljesen különböző mühelyeket használtak. Zala megyéből egyelőre nem ismerünk vasolvasztó telepet, kohót, csak kovácsmühelyeket. Viszont Zalaváron Szőke Béla Miklós két ékelt vasbucát ${ }^{57}$ talált, ezek más nyersanyagokkal, pl. az üvegolvasztás és a bronzöntés nyersanyagaival érkezhettek ide a salzburgi érsek adományaként.

A 9. századi Dunántúlon - a szabadon álló kohók mellett - feltehetően tovább használták az avar korból hagyományozódott beépített kohókat is (erre utalhat Bátaszék késő avar kori és Bodrog-Alsóbű 9(?)/10 századi kohótelepe). Utóbbi esetben feltételezhető, hogy a mesterséget folytató népcsoport - ha alávetett állapotban is - de megtalálhatta helyét az újjáalakított-Karoling kori társadalom gazdasági szervezetében, majd a magyar honfoglalás után, a 10. század elején már a hagyományos kohóiban folytatta a vaskohászatot.

48 E helyen csak részletezés nélkül hivatkozom a vonatkozó szakirodalmat bőségesen idéző kerámiakutató megállapítására: http://real. mtak.hu/7853/1/Hadak-utjan-XX_271-286_Merva.pdf: „A késő avarok továbbélése a kutatás mai állása szerint régészetileg megfogható legalább a 9. században (SzökE 1990, 153.). A továbbélés az eddigi megfigyelések alapján a fazekas-hagyományokban is érzékelhetö."

49 GÖMÖRI 1980; GÖMÖRI 2000.

50 Angol és német szakterminológiával élve, „domestic handicraft” (MARTENs 1977.) keretében, „Bauern Rennfeuer” (Pittioni) alkalmazásával.

51 A késő avar kori zamárdi kohászati telepén 1986-ban feltártunk (GömöRI 1987, 256-257.) egy hasonló cölöpös építményt, melynek párhuzama a bajorországi Ingolstadt Karoling-kori vasipari körzetében is megfigyelhető. A további, nagyobb kiterjedéü feltárásokról: GaLLINA - HORNOK - SOMOGYI 2006, hasonló objektumokkal.

52 GÖMÖRI 1978; GÖMÖRI 1980.

53 HENSCH 2016, 32.

54 SZÖKE 2010.

55 Augustus és Tiberius pannoniai hódításait követő provinciaszervezések után a helyben talált - igaz, hogy egy időre rezervátum szerủ civitasokba kényszerített - észak-nyugat pannóniai kelta boi törzs fazekasai, a késői La Tène korban használt égetőkemence formákat és szerkezeteket alkalmazták a scarbantiai fazekas-telepeken is, az új igények szerint készített edényeik kiégetésénél. A római kor előtti, több évszázados kelta kolonizáció olyan szívósan továbbélő alaplakossággal népesítette be a Plinius által később deserta Boiorumnak nevezett, valójában nem lakatlan vidéket, amely Pannonia tarka etnikumú népességének a római uralom korai év századaiban is egyik meghatározó eleme maradt.

Feltételezhető, hogy a magyar honfoglalás előtt is élhettek itt több évszázados kézműves hagyományokat ápoló népcsoportok, amelyek a fenti kelta példához hasonlóan „kolonizálták” vagyis benépesítették ezt a vidéket. GöMöRI 2001a; GöMÖRI 2005a 131-138; GöMÖRI 1999b; GÖMÖRI 2012b; GÖMÖRI 2012c; GÖMÖRI 2016.

56 SZÖKE 1999.

57 SzöKE 2014. A vasbuca bemutatása a szegedi szimpóziumon (2016) és a prágai archeometallurgiai konferencián (2017) konferencián történt: TöRök Eт AL. 2017. https://archeoindustrysites.com/sites/default/files/pdf/8-9-szazadi-hasitott-vasbucak-osszehasonlitovizsgalta-poster-tb-114-blooms.pdf; TöRö́ ET AL. 2018. 
Ez a mủhelygödör oldalába épített kohótípus jelenti a kontinuitást, amely a 9. században majdnem megszakadt, mert az avar hagyományokkal is rendelkező (pl. Iván-Dudás-dűlő, Dénesfa-Szíkas-dűlő), és a Karoling-kori bajor kohászatban elterjedtebb, nagyobb kapacitású, szabadon álló kohókat alkalmazták a pannóniai Ostmark centralizált fegyvergyártó vasipari telepein is.

A szabadonálló kohótípus használata - jelenlegi ismereteink szerint - a Karoling-kor után, (vizsgált területünkön: Sopron megye, és Somogy megye) rövidesen megszűnt. Így a nagyobb (lábodi típusú). 8-10 kilogrammos bucák helyett a kisebb (somogyfajszi típusú), 2-3 kilogrammos bucák elóállítására volt lehetőség a magyar honfoglalás után még a 12-13. századig működő kis méretű buca-kemencékben.

A fennmaradó kérdések között az egyik legfontosabb, hogy megtaláljuk a kapcsolatot a Kárpát-medence korai kohászati emlékanyaga, továbbá Etelköz és körzete, esetleg a még korábbi magyar szállásterületek vasipari lelőhelyei között. A vállalkozás nem lenne reménytelen, hiszen a feltételezhető őshazák és szálláshelyek körzeteiben is találtak már vasrégészeti műhelymaradványokat, a Dél-Uráltól Kazahsztánig és Baskíriáig.

\title{
Questions of the technological continuity in the light of the glowing iron blooms found at the sites in Somogy county
}

\author{
JÁNOS GÖMÖRI
}

The comparison of the eight-century Avar, ninth-century Pannonian Carolingian and the tenth-eleventhcentury post-Conquest period, early medieval bloomery furnaces and the iron blooms found in their proximity suggested that of the two furnace types used during the late Avar period in Pannonia, open-air clay furnaces with slag tapping and a clay breast panel were used in the ninth-century duchies of the Frankish-Bavarian Ostmark. One good example of the industrial workshops producing weapons can be cited from Nemeskér near Sopron, where slag heaps, charcoal pits and smith workshops were uncovered. The iron blooms weighing 8-10 $\mathrm{kg}$ were probably produced in these furnaces (e.g. at Lábod-Petesmalom). Their counterparts with similar sizes are the iron blooms found at Zalavár (Mosaburg) that had probably been sent to Pannonia by the archbishop of Salzburg in the mid-ninth century.

In Counties Somogy and Tolna, the most frequent type was the furnace recessed into the workshop pits; similar workshop pits were established and used continuously in the tenth century and eventually became general during the eleventh-twelfth centuries across the medieval Kingdom of Hungary. These furnaces produced blooms weighing $2-3 \mathrm{~kg}$. The technological continuity suggests the presence of a local population with stable craft skills preserving the late Avar traditions; this population can probably be identified with the Ungri of the ninth-tenth-century written sources, who are often equated with the late Avars. The same ethnonym also denoted one of the tribes of the Hungarian tribal alliance during this period. The name can be derived from the Onogur tribal alliance, which according to some leading linguists is a variant of the ethnonym Ungarus, Hungarus denoting the Hungarians.

\section{Irodalom}

ÁGH - GöMÖRI 1999 Ágh, József - Gömöri, János: Investigation of materials from the Somogyfajsz workshop. A somogyfajszi mühely anyagainak vizsgálata. In: Gömöri, János (ed.): Traditions and Innovations in the Early Medieval Iron Production. Hagyományok és újítások a korai középkori vaskohászatban. Sopron-Somogyfajsz, 1999. 192-198.

BÁLINT 2004 Bálint Csanád: A középavar kor kezdete és Kuber bevándorlása. Archaeologiai Értesítő 129. 36-65.

BENKÖ - GÖMÖRI 1990 Benkő, Lázár - Gömöri, János: Early medieval iron-smelting furnaces in Western Hungary and their dating by thermoluminescence. In: Zkoumáni vyrobních objektu a tecnologií archeologickymi metodami. Brno, 1990. $3-25$.

Czövek 2010 Czövek Attila: Avar kori kohótelep Bátaszék határában. A Wosinsy Mór Megyei Múzeum Évkönyve 32. $214-241$.

ESPELUND 2013 Espelund, Arne: The evidence and secret of ancient bloomery irommaking in Norway. Trondheim, 2013.

Galuina - Hornok - Somogy 2006 Gallina Zsolt - Hornok Péter - Somogyi Krisztina: Előzetes jelentés a Zamárdit elkerülő 65101. sz. út Zamárdi 89, 58a, 58b, 56. lelöhelyeinek feltárásáról (Preliminary report of the excavations of the sites No. 89, 58a, 58b, 56. on the encircling road No. 65101 around Kaposvár). Somogy Múzeumok Közleményei 17/A. 153-168.

GöMÖRI 1976 Gömöri János: Die Erforschung der Burg der Geschpanschaft von Sopron und ihre Umbebung in den Jahren 1971-74. Acta Archaeologica Hungaricae 28. 411-424. 
GöMÖRI 1978 Gömöri János: Jelentés a nyugat-magyarországi vasvidék régészeti kutatásáról I. Arrabona 19-20. (1977-78) 109-158.

GöMÖRI 1979 Gömöri János: Jelentés a nyugat-magyarországi vasvidék régészeti kutatásáról II. (Meldung über die Forschungen der Fundorte des west-ungarischen Eisenerzgebiete im Komitate Győr-Sopron II. Die Ausgrabung in Kányaszurdok und die Frage der gespaltenen Eisenluppen aus Sopron (Ödenburg)). Arrabona 21. 59-86.

GömÖRI 1980 Gömöri János: Frühmittelalterliche Eisenschmelzöpfen von Tarjánpuszta und Nemeskér. Acta Archaeologica Hungaricae 32. 317-345.

GömöRI 1981 Gömöri János: A korai vasolvasztó kemencék és az ékelt vasbucák kérdése (On the problem of early Mediaval iron smelting furnaces and the split iron blooms). In: Gömöri János (szerk.): Iparrégészet Égetőkemencék I. Industrial Archaeology I. Kilns and furnaces. Veszprém, 1981. 109-121.

GöMÖRI 1984 Gömöri János: A dénesfai vasolvasztó kemence feltárása. BKL, Kohászat 117/11-12. 537-539.

GöMÖRI 1987 Gömöri János: Jelentés az 1986. évi zamárdi vaskohóásatásról. BKL, Kohászat 120/5. 256-257.

GömÖRI 1988 Gömöri, János: The Szakony Blommery Workshops. In: Sperl, Gerhard (ed.): Il primo ferro nel Mediterraneo. Atti del Convegno di Populonia/Piombino 1983. PACT, Journal of the European Study Group on Physical, Chemical, Biological and Mathematical Techniques Applied to Arceolology, Strasbourg, Council of Europe. 21. Strasbourg, 1988. 101-110.

GömörI 1989 Gömöri, János: The Hungarian Bloomeries. In: Pleiner, Radomír (ed.): Archaeometallurgy of Iron $1967-1987$. Prague, 1989. 125-138.

GöMÖRI 1996 Gömöri János: 10. századi vasolvasztó műhely Somogyfajszon. BKL, Kohászat 129/7-8. 270-279.

GöMÖRI 1999a Gömöri, János: Medieval (10-12 th c.) iron mine and furnaces near Kópháza (Western Hungary). Korai középkori vasércbánya és vasolvasztó kohó Kópházán. In: Gömöri, János (ed.): Traditions and Innovations in the Early Medieval Iron Production. Hagyományok és újitások a korai középkori vaskohászatban. Sopron-Somogyfajsz, 1999. 130-141.

GömöRı 1999b Gömöri, János: Nemeskér type iron smelting workshops from the time of the Onogur colonization of Pannonia. Excavations in Zamárdi. Nemeskéri típusú vasolvasztó műhelyek Pannonia onogur kolonizációjának időszakából. A zamárdi kohótelep. In: Gömöri, János (ed.): Traditions and Innovations in the Early Medieval Iron Production. Hagyományok és újítások a korai középkori vaskohászatban. Sopron-Somogyfajsz, 1999. 149-159.

GömöRI 2000a Gömöri János: Az avar kori és Árpád-kori vaskohászat régészeti emlékei Pannoniában. Magyarország iparrégészeti lelöhelykatasztere I. Vasmüvesség. Sopron, 2000.

GömöRI 2000b Gömöri János: Az avar kori és X-XI. századi vaskohászat régészeti emlékei Somogy megyében (The archaeometallurgical sites of county Somogy in the Avar and early Árpád-period). Somogyi Múzeumok Közleményei 14. 163-218.

GöMÖRI 2000c Gömöri János: A honfoglaló magyarok vasgyártása a régészet tükrében. In: Ágh József et al. (szerk.): A bucakemencétől az integrált acélgyártásig. Nemzetközi ipartörténeti konferencia előadás-gyűjteménye. Dunaújváros, 2000. 11-32.

GöMÖRI 2001a Gömöri János: Az Árpád-kori vaskohászat avar kori előzményeinek kérdése. In: Bessenyei József (szerk.): Tanulmánykötet Heckenast Gusztáv emlékére. A Miskolcon 2000. március 24-25. napján megtartott emlékkonferencia elöadásai. Miskolc, 2001. 17-35.

GömÖRI 2001b Gömöri János: Adatok az Árpád-kori vaskohászat avar kori előzményeihez I. rész. BKL, Kohászat 133/12. 474483., II. rész. BKL Kohászat 134/2. 33-38.

GöMÖRI 2005a Gömöri, János: Archaeological remains of iron production sites in the Carpathian Basin from the Avar-OnogurBolgar period. In: International Symposium, Metallurgy in Southeast Europe from ancient times till the end of $19^{\text {th }}$ century. Sofia, 2005. 131-138.

GöMÖRI 2005b Gömöri János: A Kárpát-medence kézművessége a magyar honfoglalás előtt. In: Szulovszky János (szerk.): A magyar kézmüvesipar története. Budapest, 2005. 31-38.

GömöRI 2008 Gömöri János: Az avar, onogur és magyar „lovas-népek” pannóniai vaskohászatának keleti kapcsolatairól (The Eastern Connection of the Iron Production of the Pannonian Avar, Onogur and Hungarian „Equestrian People”). In: A magyarság és Kelet Il. őstörténeti konferencia-Régészet. 2007. augusztus 17-18. A Magyarok VII. Világkongresszusának kötetei II. Budapest, 2008. 63-81.

GöMÖRI 2011 Gömöri, János: Archaeometallurgy in Hungary: some results and Questions. In: Hošek, Jiří - Cleere, Henry Mihok, L'ubomír (eds.): The Archaeometallurgy of Iron. Recent Developments in Archaeological and Scientific Research. Prague, 2011.65-72.

GÖMÖRI 2012a Gömöri János: A pannóniai római kori vaskohászat továbbélésének kérdése. A Sopron-Deák téri Árpád-kori vasolvasztó műhelyek (Die Frage des Weiterlebens der römerzeitlichen Eisenverhüttung in Pannonien). In: Vida Tivadar (szerk.): Thesaurus Avarorum. Régészeti tanulmányok Garam Éva tiszteletére. Budapest, 2012. 25-36. 
GömöRI 2012b Gömöri János: The legacy of 9th century craftsmen in the Carpathian Basin. In: Szulovszky János (ed.): The History of Handicraft in Hungary. Budapest, 2012. 17-24.

GöMÖRI 2012c Gömöri János: Vasolvasztó kemencék Zsira-Kenderszer-dűlőben. Soproni Szemle 66/1. 31-39.

GÖMÖRI 2016 Gömöri János: A Tárkány helynevekről régészeti megközelítésben (An archaeological perspective on the Tárkány (tarkhan) toponyms). In: Kovács László - Révész László (szerk.): Népek és kultúrák a Kárpát-medencében. Tanulmányok Mesterházy Károly tiszteletére. Budapest, 2016. 439-460.

GöMÖRI ET AL. 1992 Gömöri János - Verő József - Ivancsics Jenő - Csongor Éva - Szende Katalin: Une mine de fer et des fourneaux médiévaux sur le territoire de Kópháza. In: 113. Congr. Intern. sav. Strasbourg 1988. -Techniques miniéres. Paris, 1992. 149-165

GöMÖRI ET AL. 1999 Gömöri János - Márton Péter - Hertelendi Ede - Benkő Lázár: Dating of Iron Smelting Furnaces Using Physical Methods. Vasolvasztó kohók fizikai kormeghatározásai. In: Gömöri, János (ed.): Traditions and Innovations in the Early Medieval Iron Production. Hagyományok és újítások a korai középkori vaskohászatban. Sopron-Somogyfajsz, 1999. 142-148.

GÖMÖRI - MAGYAR 1999 Gömöri János - Magyar Kálmán: Az 1999. évi ásatás Bodrog-Alsóbű vasolvasztó műhelyében, rovásírásos agyagfúvó. Excavation in the Iron Smelting Workshop at Bodrog-Alsóbű in 1999, Clay Twyer with a Szekel Runiform Script. In: Gömöri, János (ed.): Traditions and Innovations in the Early Medieval Iron Production. Hagyományok és újítások a korai középkori vaskohászatban. Sopron-Somogyfajsz, 1999. 212-225.

GöMÖRI - TöRök 2002 Gömöri János - Török Béla: Technical Examination of the Early Medieval Ferrous Metallurgical Finds from Hungarian Sites. In: Archeometry 98. Procedings of the 31 st Symposium Budapest, April 26 - May 31998 Volume II. BAR International Series 1043 (II). Oxford, 2002, 375-381.

GömÖRI - GYÖRKE 2016 Gömöri, János - Györke, Réka: A new homepage, the „Archeoindustrysites”; details about the collection of iron blooms and iron bars found in Hungary. Presentation at the Symposium in Szeged, 21.09.2016.

GYÖRFFY 1958 Győrffy György: A magyarok elődeiről és a honfoglalásról. Budapest, 1958.

GYÖRKE ET AL. 2014 Györke Réka - Fintor Krisztián - Bozsó Gábor - Szabó Máté: Bátaszék-Nagyorros avar kori kohótelep érc- és salakanyagának archeometriai elemzése (Archaeometrical investigation of finds found in the Late Avar Age bloomery workshops at Bátaszék-Nagyorros [Country Tolna, Hungary]). Archeometriai Mühely 2014/1. 61-69.

HARMATTA 1996 Harmatta János: A zamárdi avar nagyszíjvég rovásírásos és szogd feliratai. Somogyi Múzeumok Közleményei 12. 107-112.

HECKENAST 1970 Heckenast Gusztáv: Fejedelmi (királyi) szolgálónépek a korai Árpád-korban. Értekezések a történettudományok köréből 53. Budapest, 1970.

HeGedüs 1961 Hegedűs Zoltán: A diósgyőri Központi Kohászati Múzeum és a soproni Liszt Ferenc Múzeum vasbucáinak kohászattörténeti vonatkozásai. Történelmi Szemle 1961. 94-106.

Hegedüs 1962 Hegedűs, Zoltán: Loupes de fer dans les musées hongrois. Revue d'Histoire de la Sidérurgie 3/1. $197-207$.

HeInRICH-TAMÁska 2013 Heinrich-Tamáska, Orsolya (Hrsg.): Keszthely-Fenékpuszta: Katalog der Befunde und ausgewählter Funde sowie neue Forschungsergebnisse. Budapest, 2003.

HoLLó - VERŐ 1979 Holló Lajos - Verő József: Geofizikai mérések a Magyarfalva (Harka)-kányaszurdok-i vaskohónál. Arrabona 21. 109-112.

Hosszú - ZeLLIGER 2014 Hosszú Gábor - Zelliger Erzsébet: A bodrog-alsóbűi rovásemlék számítógépes írástörténeti kapcsolatai és egy olvasati kísérlete. Magyar Nyelv 110/4. 417-431.

HensCH 2006 Hensch, Mathias: Neue archäologische Aspekte zur mittelalterlichen Geschichte des Frauenbergs. In: Rind, Michael (Hrsg.): Der Frauenberg Oberhalb Kloster Weltenburg / Teilband 1. Regensburger Beiträge zur prähistorischen Archäologie Band 16. Regensburg, 2006. 341-433.

HeNSCH 2016 Hensch, Mathias: Eisen für König, Reich und Adel. Zu den mittelalterlichen Anfängen des Montanwesens in der mittleren Oberpfalz. Bayerische Archäologie 2. 30-37.

JoutTIJÄRVI - Voss 2011 Jouttijärvi, Arne - Voss, Olfert: The oldest iron smelting furnaces in Denmark. In: Hošek, Jiří - Cleere, Henry - Mihok, L'ubomír (eds.): The Archaeometallurgy of Iron. Recent Developments in Archaeological and Scientific Research. Prague, 2011.55-64.

KöLtő 1999a Költő László: Előzetes kutatási eredmények az Alsóbogát-Csalánosi-dűlőben felfedezett vaskohászati lelőhelyen (Preliminary report about the early medieval furnaces of Alsóbogát-Csalánosi site). In: Gömöri, János (ed.): Traditions and Innovations in the Early Medieval Iron Production. Hagyományok és újítások a korai középkori vaskohászatban. Sopron-Somogyfajsz, 1999. 204-206.

KöLtổ 1999b Költő László: Korai vaskohászati lelőhelyek kutatása. In: Múzeumi Tájékoztató 1999/3-4. 18-21. (Kaposvár) 
KöLtő - FehÉr 2016 Költő László - Fehér András: Awarenzeitliche gespaltene Eisenluppe von Lábod-Petesmalom (Komitat Somogy) / Investigation of a split iron bloom from the Avar period from the site Lábod-Petesmalom (Somogy County) / Avar kori „ékelt" vasbuca Lábod-Petesmalom lelőhelyről. A 2016. évi szegedi konferencián elhangzott előadás. Presentation at the Symposium in Szeged, 21.09.2016)

KöLtő - SzENTPÉTERI 1996 Költő László - Szentpéteri József: A 8-10. századi kontinuitás kérdései a vörsi 8-10. századi temető kapcsán (The Questions of Continuity in the 8-10th Century on the Basis of the 8-10 th Century Cemetery Excavated at Vörs). In: Balazic, Janez - Vándor, László: Ljudje ob Muri - Népek a Muramentén - Völker an der Mur - Ljudi uz Muru: Zbornik referatov mednarodne znanstvene konference v Lendavi, 10.-12. maj 1995. Murska Sobota-Zalaegerszeg, 1996. 101-109.

LENGYEL 1999 Lengyel Károly: Amíg az öntödéből múzeum lett... Kiszely Gyula, az Öntödei Múzeum alapítója emlékére. Öntödei múzeumi füzetek 5. Budapest, 1999.

MARTENS 1977 Martens, Irmelin: Vor- und frühgeschichtliche Eisenverhüttung in Südnorwegischen Gebirgsgegenden. Wissenschaftlichten Arbeiten Burgenland 59. 147-155.

MÁrTon - GömÖrı 1991 Márton, Péter - Gömöri, János: Application of Archaeomagnetic Directional Results for the Dating of Iron-smelting Furnaces of Early Medieval Age from W-Hungary. In: Archeèologie expeèrimentale : actes du Colloque International Expeèrimentation en Archeèologie, bilan et perspectives, tenu à l'Archeèodrome de Beaune les 6,7,8 et 9 avril 1988. Paris, 1991. 133-138.

Novákı 1968 Nováki Gyula: A magyarországi vaskohászat régészeti emlékei. In: Heckenast Gusztáv - Nováki Gyula Vastagh Gábor - Zoltay Endre: A magyarországi vaskohászat története a korai középkorban (A honfoglalástól a 13. század közepéig). Budapest, 1968. 13-76.

PLEINER 2000 Pleiner, Radomír: Iron in archaeology: the European bloomery smelters. Praha, 2000.

RozsNOKI 1979 Rozsnoki Zsuzsanna: Nyugat-magyarországi vasbucákfémtani vizsgálata (The metallographycal investigations of the iron blooms found in Western Hungary). Arrabona 21. 87-107.

SÁGI 1979: Sági Károly: A fenékpusztai V. századi vasbucák történeti háttere (The historical background of the iron blooms from the 5th century AD, found in Keszthely-Fenékpuszta). Arrabona 21. 113-115.

SzŐKE 1999 Szőke Béla Miklós: A Dunántúl lakossága és a honfoglaló magyarok. In: Magyarok térben és időben. Tudományos füzetek 11. Tata, 1999. 73-103.

SzŐ́ke 2010 Szőke Béla Miklós: Mosaburg/Zalavár und Pannonien in der Karolingerzeit. Antaeus 31-32.9-52.

SzŐKE 2014 Szőke Béla Miklós: A Kárpát-medence a Karoling-korban: A Magyar Nemzeti Múzeum régészeti kiállításának katalógusa. Budapest, 2014.

SZŐKE - WEDEPOHL - KRONz 2004 Szőke Béla Miklós - Wedepohl, Karl-Hans - Kronz, Andreas: Silver-Stained Windows at Carolingian Zalavár, Mosaburg (Southwestern Hungary). Journal of Glass Studies 46. 85-104.

THIELE 2014 Thiele Ádám: A foszfor szerepe a vas archeometallurgiájában. PhD értekezés, BME, Kézirat, Budapest, 2014.

Török ET AL. 2017 Török, Béla - Költő, László - Fehér, András - Barkóczy, Péter - Kovács, Árpád - Szőke, Béla Miklós: A complex comparative study of early medieval split blooms from Pannonia. Iron in Archaeology. Bloomery smelters and blacksmiths in Europe and beyond. International Conference in Prague, 30th May - 1st June 2017. Abstract and poster. https://archeoindustrysites.com/sites/default/files/pdf/8-9-szazadi-hasitott-vasbucak-osszehasonlito-vizsgalataposter-tb-114-blooms.pdf

Török ET AL. 2018 Török Béla - Kovács Árpád - Barkóczy Péter - Költő László - Fehér András - Szőke Béla Miklós: Pannóniai kora középkori ékelt vasbucák összehasonlító archeometriai vizsgálata. BKL, Kohászat 151/3. 1-4.

VASTAGH 1977 Vastagh, Gábor: Einige Eigentümlichkeiten der ungarischen Rennfeuer-Verhüttung. Wissenschaftliche Arbeiten aus dem Burgenland 59. 101-105.

VERÖ 1984 Verő József: A dénesfai vasolvasztók környékén végzett geofizikai mérések. BKL, Kohászat 117/11-12.539.

VERÖ 1988 Verő, József: Exploration of archaeological sites in Western Hungary by the geomagnetic method. In: Járó, Márta - Költő, László (eds.): Archaeometrical research in Hungary. Budapest, 1988. 29-33.

Voss 1989 Voss, Olfert: Iron Furnaces in Denmark. In: Pleiner, Radomír (ed.): Archaeometallurgy of Iron 1967-1987. Prague, 1989. 151-157.

ZoltAY 1968 Zoltay Endre: Az egykori vasgyártás technológiája a próbaolvsaztások tükrében. In: Heckenast Gusztáv - Nováki Gyula - Vastagh Gábor - Zoltay Endre: A magyarországi vaskohászat története a korai középkorban (A honfoglalástól a 13. század közepéig). Budapest, 1968. 172-232. 
